\title{
Editorial
}

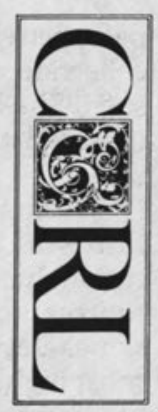

\section{Alice Spitzer, Library Superstar}

"I would like to nominate Ms. Alice Spitzer for your series on 'library superstars: librarians who excel in serving their campus communities.' Alice Spitzer is a public services librarian at Washington State University (WSU) libraries. She is definitely one of those individuals who 'works harder, smarter, longer, and better than anyone else around.' Alice deserves recognition for both the quality and quantity of assigned job responsibilities. Her initiative and willingness to assume additional workload, to volunteer for additional library service, and to host social activities on a continuing basis over her entire employment history at WSU (from October 1975 to date) is incredible.

"Alice not only provides reference desk assistance for approximately 12-15 hours per week, but she manages a humanities/social sciences serials records unit, supervising the work of 9.5 F.T.E. classified staff positions. This position also requires close liaison with technical services serials records personnel and science libraries' serial records personnel. In addition, she is the humanities/social sciences library user education coordinator, an Asian Studies faculty member, and she is responsible for collection development in language, literature, linquistics, non-Western art; Asia and Asian Studies; and Middle East, African, Slavic, and Scandinavian languages and literature.

"In addition to scheduling the lower division library user education activities and serving as the liaison to the English composition faculty, Alice has, during the past year, taught library use skills to over 2,000 students in English composition, expository writing, English as a second language, speech communications, education, and local elementary and secondary English classes-a total of 150 classroom hours. This includes over 100 hours in preparation for classroom presentations, 200 hours in designing instructional guides and library assignments related to course curricula, another 250 hours in working with teaching faculty to integrate library instruction into the curriculum, and 100 hours in meetings to assist faculty teaching a pilot world civilizations course (funded by the National Endowment for the Humanities) integrating content, writing, and library assignments with English composition courses.

"At Alice's initiative, the university administration and faculty senate have taken steps to ensure that librarians and the libraries are an integral part of the General Education Commission and the All-University Writing Committee in preparation for a major general education curriculum reform.

"As part of her responsibilities in the general education curriculum reform, Alice has completed an inventory of relevant slides, films, maps, and other library resources relating to world civilization from 500 в.C. to the present, including materials on many different civilizations and cultures. In order to complete this project, Alice demonstrated her knowledge of, and expertise in, identifying the concepts to be studied: major and minor artistic, scientific, literary, historical, and political figures; and major events in such fields as anthropology, history, literature, the arts, sociology, psychology, and political science.

"Her expertise in international relations and development has contributed greatly to the 
perspective and progressive development of all general education courses and supportive collection development. Alice has far more than a textbook approach to international issues. She has served on international development projects in several third-world countries. Most recently, she assisted in the development of a small research center library in the Sudan.

"During this past year, she also served as a consultant to a Washington D.C. consulting firm working with third-world countries. Washington State University, a land-grant institution, has close ties with many developing countries and with Pacific rim countries. Alice Spitzer is one of the first persons to be contacted when assistance is needed by the International Development Office and/or faculty serving on overseas projects. She is one of the most highly respected members of the university's Committee to Review Memorandums of Understanding and Public Service Grants related to International Development Projects. Alice was the primary initiator of a very successful national conference held on cam. pus for librarians involved in international development projects. This effort has literally put WSU on the map: as stated in L J Hotline, 'WSU Libraries is taking the lead in international development.'

"Alice has built an unequalled reputation on this campus as a leader and expert in many different areas of responsibility. There are few researchers, faculty, and students who do not know her, and even fewer who have not attended one of the many social gatherings held at her home to acquaint faculty and administrators with new university employees, to introduce visiting lecturers, or to celebrate some facet of university life. Alice is considered an excellent librarian, a teaching colleague, and a friend to everyone in the university and surrounding community.

"I might add that not only has she gone beyond expectations in assigned and volunteer job duties, but she has published two articles this past year on user education, another one on international development and librarians, and she's in the process of completing a fourth one on integrating library user education into the general education curriculum.

"Alice Spitzer's superb abilities as a librarian, a teacher, and a leader in community activities help to motivate and inspire the rest of us. It's time we demonstrate our appreciation by nominating her as one of our superstars!"-Maureen Pastine.

These words were written by Maureen Pastine, Director of Libraries at Washington State University. Our profession is extremely fortunate to have colleagues, such as Alice Spitzer, who demonstrate daily the qualities of service excellence, initiative, and dedication on behalf of their campus communities.

Many of you have written in to nominate a library superstar. Librarians from states such as Georgia, Indiana, Michigan, and Pennsylvania have been lauded. One major, and interesting, constant has been the degree to which these superstar nominees inspire their colleagues and act as models of excellence.

One of the librarians who was nominated, John A. Edens, works in technical services. His activities clearly influence direct client services and he deserves consideration. Leslie M. Dees worked with John during the mid-70s when he was at the Georgia Institute of Technology. In nominating him, Leslie says that he expected people to give a full day's work for a full day's pay; he expected people to care enough about their jobs to do them correctly; and, he always demanded more of himself than of anyone else. John is now Director of Central Technical Services at the State University of New York in Buffalo.

In forwarding your nominees, focus on direct user services, or if the person is in technical services or administration, show how the efforts of your nominee have resulted in the creation or provision of high quality services to his or her various constituencies. Also, the words that you provide in support of your nominee are the "objective evidence" that I must use in making comparisons among nominees for inclusion in future editorials. It is therefore likely that I will use your words to carry the message about your library superstar to the readers of College \& Research Libraries.

CHARLES MARTELL 


\section{The World's Most Prestigious Prize}

The only comprehensive, fully narrative biographical reference work of its kind available, Nobel Prize Winners presents accurate and incisive profiles of the 566 men, women, and organizations that have received the Prize between 1901 and 1986.
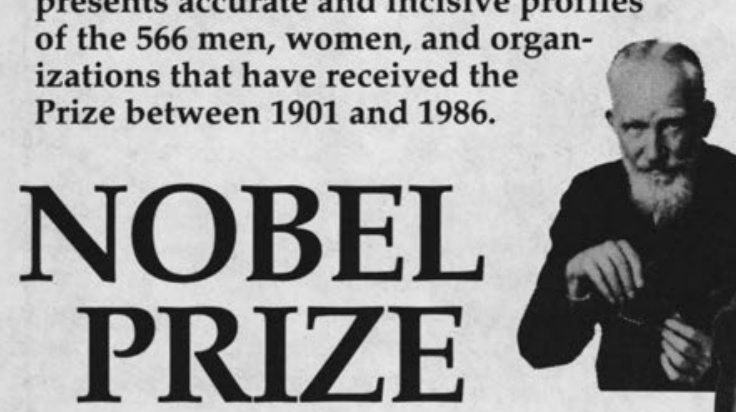

ALnuvoke ruade

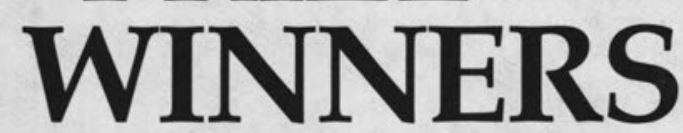

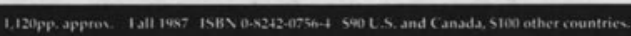

The Men and Women Who Changed the World

Ideal for both students and the general reader, Nobel Prize Winners provides a fascinating look at such epoch-making events as Einstein's formulation of the General Theory of Relativity; Crick and Watson's elucidation of the DNA molecule; Martin Luther King, Jr.'s crusade for equality and social justice; Marie Curie's discovery of radium; the publication of Aleksandr Solzhenitsyn's novels in the West; and the creation of econometrics by Ragar Frisch, to name just a few.

\section{Convenient and Easy-to-Use}

Arranged alphabetically by last name, the entries in Nobel Prize Winners provide a 1,200 to 1,500 word essay on the laureate, and include:

- Information on the laureate's early development, family background, and formative influences.
- A description of the work for which the prize was awarded.

- A critical evaluation of the laureate's contribution to his field.

- A photograph of the laureate.

- A bibliography citing works by, and about the subject.

- A chronological table listing laureates by prize category, plus an alphabetical listing of all Prize recipients.

\section{Nobel Prize Winners-}

Five Year Supplements

Nobel Prize Winners will retain its value as a reference source for years to come: every five years, beginning in 1992, supplements to Nobel Prize Winners will be published, covering the approximately 60 Nobel Prizes awarded in the intervening period.

\section{Nobel Prize Winners} Advisory Board

Gert H. Brieger, M.D., Johns Hopkins University; Erwin N. Hiebert, Harvard University; Martin J. Klein, Yale University; Erik F. Lundberg, Royal Swedish Academy of Sciences, Nobel

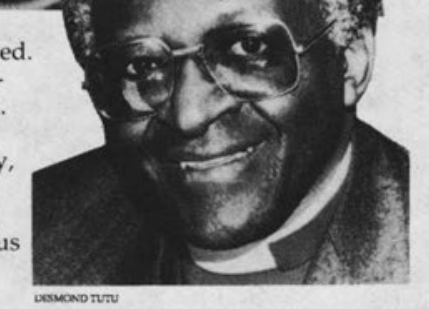

Committee for Economics; William McGuire, Bollingen Foundation; Alden Whitman, The New York Times.

To Order Call Toll-Free: 1-800-367-6770

In New York State call 1-800-462-6060; in Canada call collect 212-588-8400.

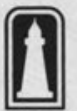

THE H.W. WILSON COMPANY

950 University Avenue Bronx, New York 10452 (212) 588-8400 


\section{Announcing an important new series... INFORMATION MANAGEMENT, POLICIES, AND SERVICES

\author{
edited by Charles R. McClure and Peter Hernon
}

Ablex Publishing Corporation is pleased to announce a new monograph series, INFORMATION MANAGEMENT, POLICIES, AND SERVICES. The series will be edited by Charles R. McClure, Professor, School of Information Studies, Syracuse University, and Peter Hernon, Graduate School of Library and Information Science, Simmons College.

The purpose of the series is to provide a broad range of scholarly texts, practical guides, and reference works related to the management, use, and application of information policies and services in a variety of contexts. The theme throughout the series is that information is a valuable resource whose better management and use can significantly improve organizational and program effectiveness, policy making, and services. The series will target publications to librarians, information managers, government/information policy makers, and researchers in library/information science, public policy, and information resources management.

Ablex Publishing Corporation has a strong record of publishing a number of successful series and individual monographs. A complete catalog listing Ablex's many titles is available directly from the publisher. Ablex offers a full range of editorial and production services, using the most up-to-date electronic publishing techniques, combined with aggressive sales and marketing strategies developed for each individual title.

Publications scheduled to appear to date in the McClure-Hernon series are:

- Michael Eisenberg \& Robert Berkowitz: Curriculum Concerns for School Media Specialists

- Peter Hernon \& John Richardson (eds.): Microcomputer Statistical Analysis Software: A Guide for Supporting Library Decision Making

- June Engle: Power, Politics and Personality: The State Library Agency as a Policy Actor

- Keith Harman: Managing Information for Competitive Positioning in Economic Development

- Peter Hernon \& Charles R. McClure: Public Access to Government Information, Second Edition

- Charles R. McClure, Peter Hernon \& Harold Relyea (eds.): U.S. Government Information Policies: Frameworks for Assessing Issues and Options

Charles R. McClure and Peter Hernon are recognized authorities on a range of topics related to library/information management, services, and policies. They have published widely on these topics and will provide editorial direction for the series, identify topics and authors to be included in the series, and assist contributing authors in the production of high quality monographs. They welcome proposals from prospective contributors for monographs to be included in the series. Potential contributors should contact the Editors directly for additional information at:

Charles R. McClure

School of Information Studies

Syracuse University

Syracuse, NY 13104

(315) 423-2911
Peter Hernon

Grad. School of Library \& Information Science

Simmons College

300 The Fenway

Boston, MA 02115

(617) $738-2223$ 